\title{
The Caddo Ceramic Sherd Assemblage from the W. T. Robinson Farm (41AN4), Anderson County, Texas
}

Timothy K. Perttula

Heritage Research Center, Stephen F. Austin State University

Follow this and additional works at: https://scholarworks.sfasu.edu/ita

Part of the American Material Culture Commons, Archaeological Anthropology Commons, Environmental Studies Commons, Other American Studies Commons, Other Arts and Humanities Commons, Other History of Art, Architecture, and Archaeology Commons, and the United States History Commons

Tell us how this article helped you.

This Article is brought to you for free and open access by the Center for Regional Heritage Research at SFA ScholarWorks. It has been accepted for inclusion in Index of Texas Archaeology: Open Access Gray Literature from the Lone Star State by an authorized editor of SFA ScholarWorks. For more information, please contact cdsscholarworks@sfasu.edu. 


\section{The Caddo Ceramic Sherd Assemblage from the W. T. Robinson Farm (41AN4), Anderson County, Texas}

\section{Creative Commons License}

\section{(c) (1) \&}

This work is licensed under a Creative Commons Attribution-NonCommercial 4.0 International License 


\title{
The Caddo Ceramic Sherd Assemblage from the W. T. Robinson Farm (41AN4), Anderson County, Texas
}

\author{
Timothy K. Perttula
}

\section{INTRODUCTION AND SITE SETTING}

The W. T. Robinson Farm site (41AN4) is one of a number of ancestral Caddo sites known in the Caddo Creek valley in the upper Neches River basin in East Texas (Figure 1). The site, about 2.5 miles northwest of Frankston, Texas, was investigated by archaeologists from the University of Texas (UT) in 1931 in an area where locals had reportedly excavated 15 Caddo vessels some 20 years earlier. The UT investigations found no Caddo burials or vessels, and recovered only a small assemblage of ceramic vessel sherds.

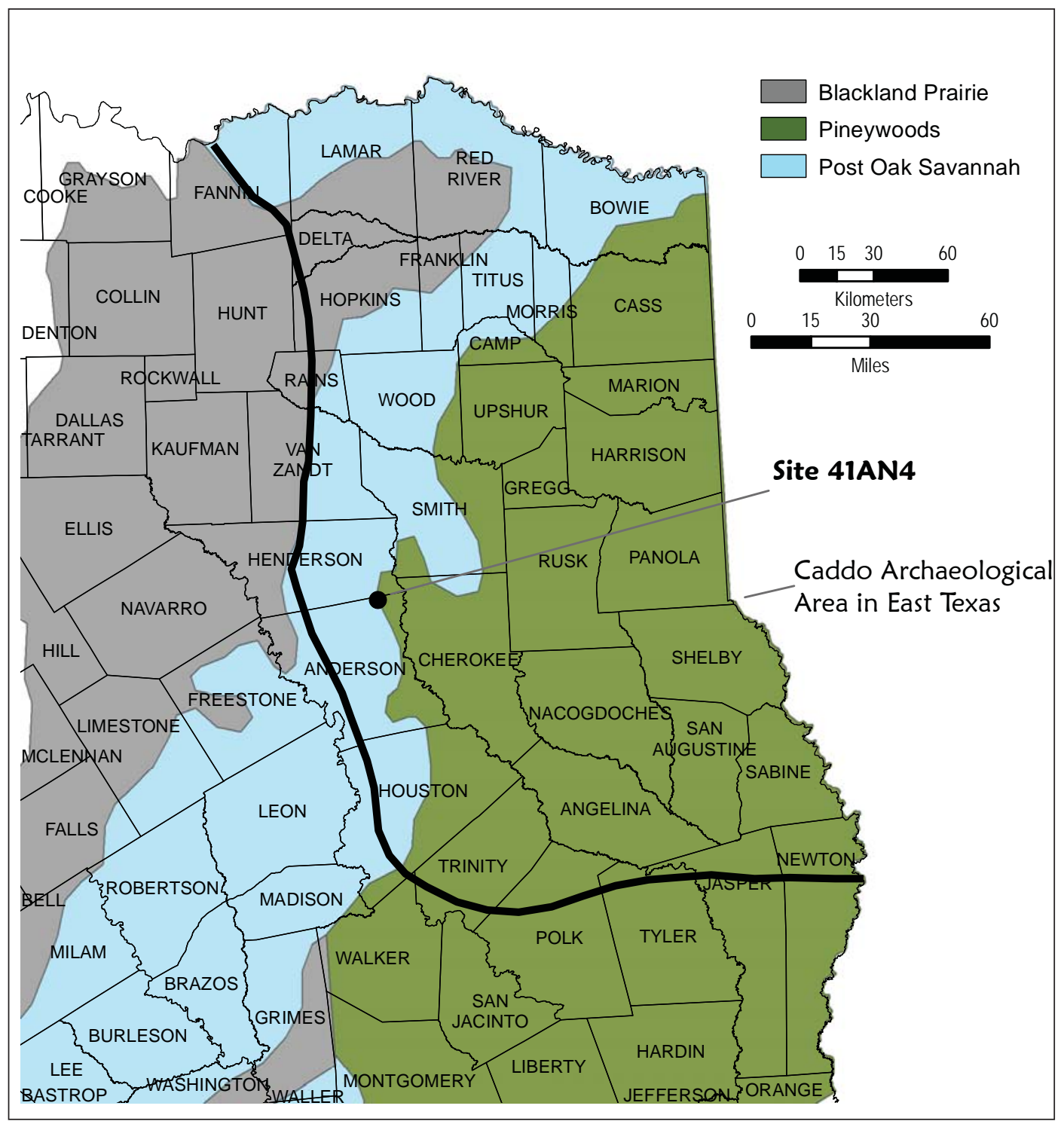

Figure 1. The location of the W. T. Robinson Farm site (41AN4) site in East Texas. 


\section{Ceramic Sherd Assemblage}

The Texas Archeological Research Laboratory (TARL) collections from the W. T. Robinson site have 77 sherds from Caddo ceramic vessels (Table 1). About 98.7 percent of the sherds are from grog-tempered vessels, and only 1.3 percent of the sherds are from bone-tempered vessels. The plain to decorated sherd ratio is 0.45 , and almost 90 percent of the decorated sherds are from utility ware jars.

Table 1. Ceramic sherds from the W. T. Robinson Farm site (41AN4).

\begin{tabular}{lccc}
\hline Ware & Grog temper & Bone temper & N \\
\hline Plain & 23 & 1 & 24 \\
Utility & 47 & - & 47 \\
Fine & 6 & 1 & 6 \\
\hline Totals & 76 & 77 \\
\hline
\end{tabular}

The 53 decorated sherds in the assemblage from the W. T. Robinson Farm site are dominated by brushed sherds from utility ware vessels (Table 2). Rim and body sherds with brushing marks comprise 77 percent of all the decorated sherds and 87 percent of the sherds from utility ware vessels. These sherds are from Bullard Brushed vessels.

Table 2. Decorated methods and decorative elements represented in the ceramic sherd assemblage from the W. T. Robinson Farm (41AN4).

\begin{tabular}{llll}
\hline $\begin{array}{l}\text { Decorative method/decorative } \\
\text { element }\end{array}$ & Rim & Body & N \\
\hline
\end{tabular}

\section{Utility Ware}

Brushed

diagonal and vertical brushing marks

horizontal brushed rim and vertical brushed

body

overlapping brushing marks

parallel brushing marks

vertical brushing marks

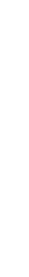

\section{Neck Banded}

horizontal neck bands

\section{Pinched}

parallel pinched ridges

\section{Punctated}

fingernail punctated rows

\section{Fine Ware}

Engraved

closely-spaced curvilinear lines

diagonal lines and diagonal hatched zone

horizontal line and sets of curvilinear and circular lines

1

1

1

36

2

(1)

3


Table 2. Decorated methods and decorative elements represented in the ceramic sherd assemblage from the W. T. Robinson Farm (41AN4), cont.

\begin{tabular}{llll}
\hline $\begin{array}{l}\text { Decorative method/decorative } \\
\text { element }\end{array}$ & Rim & Body & $\mathrm{N}$ \\
\hline $\begin{array}{l}\text { horizontal engraved line with excised pendant } \\
\text { triangles } \\
\text { horizontal engraved lines with excised } \\
\text { pendant triangles }\end{array}$ & 1 & - & 1 \\
\hline Totals & 1 & - & 1 \\
\hline
\end{tabular}

Two sherds are from La Rue Neck Banded jars (3.8 percent of the decorated sherds), and one body sherd is from a Killough Pinched jar (1.9 percent of the decorated sherds). The remaining utility ware sherds (5.7 percent of the decorated sherds) are from jars with rows of fingernail punctations encircling the upper part of the vessel.

The fine ware vessel sherds from the site have engraved decorative elements (see Table 2). Three rim and body sherds are clearly from Poynor Engraved vessels: two are body sherds with closely-spaced curvilinear lines, probably from hatched curvilinear elements at the top and bottom of engraved rim panels, and the third sherd is a rim from a Poynor Engraved, var. Cook vessel (see Perttula 2011:Figure 6-64c). with a horizontal line under the lip as well as sets of curvilinear and circular elements (Figure 2a). Another body sherd has diagonal lines and a diagonal hatched zone (Figure $2 b$ ), and this sherd may be part of the scroll fill zone on a Poynor Engraved, var. I vessel (see Perttula 2011:Figure 6-65).

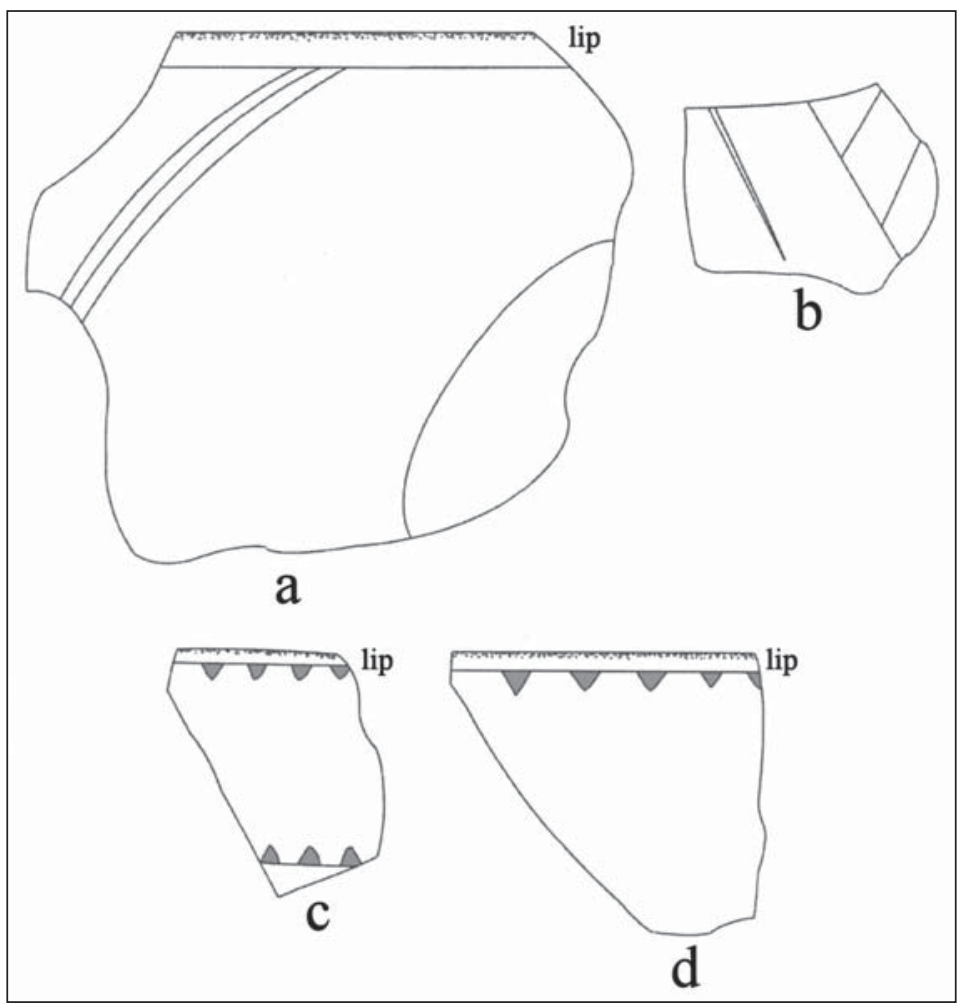

Figure 2. Selected fine ware decorative elements in the W. T. Robinson Farm site (41AN4) ceramic assemblage: a, Poynor Engraved, var. Cook rim sherd; b, possible Poynor Engraved, var. $I$ body sherd; c-d, Patton Engraved rim sherds. 
The last two engraved sherds are rims from Patton Engraved, var. unspecified vessels (see Figure 2c-d). These rim sherds have either a single horizontal engraved line under the vessel lip with excised pendant triangles or upper and lower horizontal engraved lines with excised pendant triangles pointing towards each other.

\section{SUMMARY AND CONCLUSIONS}

The ceramic sherd assemblage from the W. T. Robinson site (41AN4) is consistent with the upper Neches River basin Caddo ceramic tradition (Perttula 2011:315-318) that dates from ca. A.D. 1320-1700+. A ceramic tradition means that it is "a single, coherent, community of technological and stylistic practice specific to the Caddo peoples of this area." In this tradition, ceramics are (1) almost exclusively grog-tempered; (2) brushed utility ware pottery from Bullard Brushed vessels dominates the decorated sherd assemblages; (3) fine ware sherds are primarily from varieties of Poynor Engraved before ca. A.D. 1650 and Patton Engraved varieties after ca. A.D. 1650; and (4) plain to decorated sherd ratios (P/DR) range from only 0.14-1.50, with most of the sites having P/DR values less than 0.72 . Caddo sites of this tradition did not have many plain ware vessels. Finally, the W. T. Robinson site occupation by Caddo peoples likely dates from the late 16th to mid-17th century A.D., based on the occurrence of both Poynor Engraved and Patton Engraved fine ware sherds as well as the very high proportion of brushed utility ware sherds in the assemblage.

\section{ACKNOWLEDGMENTS}

I appreciate the assistance of Jonathan Jarvis at the Texas Archeological Research Laboratory, The University of Texas at Austin for providing access to the records and collections from the W. T. Robinson Farm site. Lance Trask prepared the figures in this article.

\section{REFERENCES CITED}

Perttula, T. K.

2011 The Ceramic Artifacts from the Lang Pasture Site (41AN38) and the Place of the Site within an Upper Neches River Basin Caddo Ceramic Tradition. In Archeological Investigations at the Lang Pasture Site (41AN38) in the Upper Neches River Basin of East Texas, assembled and edited by T. K. Perttula, D. B. Kelley, and R. A. Ricklis, pp. 145-320. Archeological Studies Program Report No. 129, Texas Department of Transportation, Environmental Affairs Division, Austin. 